\title{
設計通りに遺伝子交換
}

\section{Gene exchange by design}

Stanton B. Gelvin

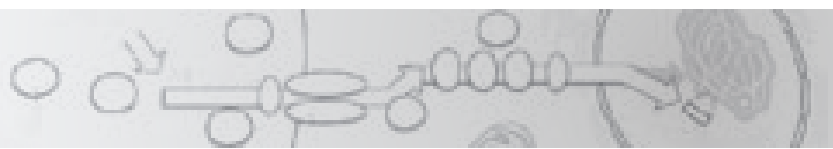

細菌から植物への遺伝子導入が可能なのは、アグロバクテリウム属の細菌に限られると考えら れてきた。ところが、アグロバクテリウム以外の細菌属にも界を越えた遺伝的交換が可能な種 が存在するようだ。

Nature Vol.433(583-584)/10 February 2005

生き物はみな、親から子へ遺伝情報を伝えることができ なければならない。この「垂直方向」の遺伝子の受け渡し がなければ、種は死に絶えるほかない。だが、生物が他 の生物へと遺伝子を受け渡す仕組みはこれだけではない。 「水平方向」の遺伝子導入が進化の主要な要因の 1 つだ とみる考え方はだいぶ以前からあり、過去に遺伝子の水 平移動が起こったと思われる例は多数ある。現在進行形 のものとしては、細菌の接合（細菌どうしが直に接触し て一方から他方へ遺伝子を受け渡すこと）が最もよく引 き合いに出される。たとえば細菌から植物へというよう に、系統分類的に異なる界の生物種どうしでの遺伝物質 の水平移動も起こりうるが、これまではアグロバクテリウ 厶属の細菌についてしか報告されたものがなかつた。今

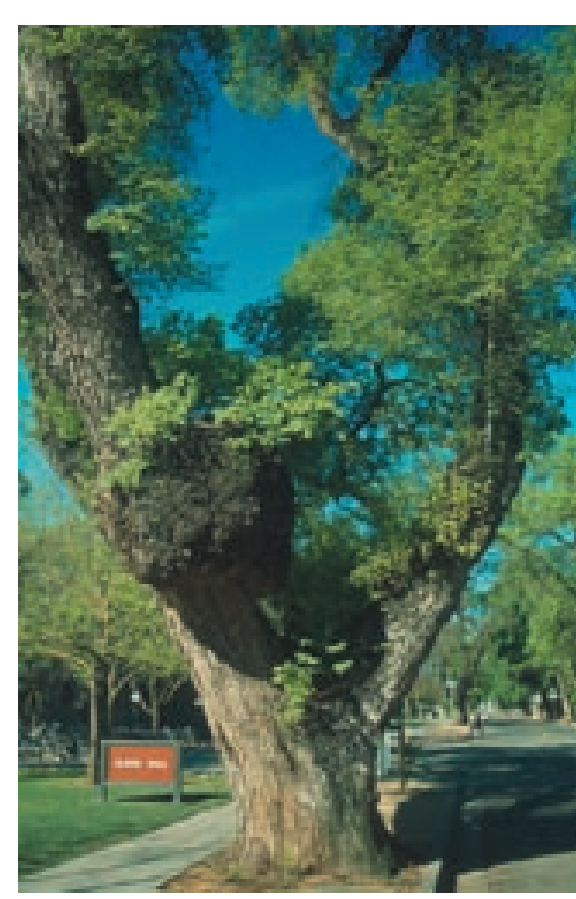

図 1 ニレの木にできた根頭癌腫病。大部分の 根頭癌腫は地面か地下の部分にできるが、この 写真のように地上部の癌腫もできる。(写真提供: Jer-Ming Hu、国立台湾大学)
回 Broothaerts たちは、この属以外 にも界を越えた「セックス」ができ る細菌種が存在することを明らかに した ${ }^{1}$ (原著論文は Nature 2/10 号 を参照のこと)。

Agrobacterium tumefaciens は病 原細菌で、根頭癌腫病という広範な 植物種がかかる腫瘍性疾患（図 1) を引き起こす ${ }^{2}$ 。A. tumefaciens は 近縁な A. rhizogenes やA. vitis、 A. rubi とともに、大きな染色体外 DNA 要素（癌腫誘導プラスミド、略 して Ti プラスミド）の一部を寄主植 物に導入して癌腫を引き起こす。こ の導入されたDNA（T-DNA）はい ったん植物細胞の内部に入ると核を 目指し、そこで最終的に宿主ゲノム に入り込む。T-DNA にコードされる 癌腫遺伝子が発現すると、ホルモン の過剰生産かホルモン感受性の異常 え進が起こって細胞増殖に対する制
御がきかなくなり、癌腫ができる ${ }^{3}$ 。

アグロバクテリウムに備わるこのような植物への DNA 導入能は、遺伝子工学に携わる研究者たちに活用されて きた。細菌の T-DNAから癌腫遺伝子を削除して、導入 したい遺伝子に置き換えられるからだ（図 2)。こうした 「導入遺伝子」を入れ込むことができれば、除草剤や病原 体に対する抵抗性、改造した成長特性や栄養摂取特性、 あるいは薬剤や食べるワクチン（植物に抗原を発現させ、 それを食べたヒトや動物に病原体に対する免疫をもたせ る）を作る能力といつた、新たな特徵を備えた植物を作 り出せる。アグロバクテリウムは実験室条件下で菌類や動 物の細胞に遺伝的形質転換を起こすこともできる ${ }^{4-6}$

アグロバクテリウムを使った遺伝的形質転換は植物の基 礎研究に欠かせないものとなっており、農業バイオ技術 産業においても遺伝子導入植物を作るための基本手段と なっている。だが少なくとも商業目的については、アグ ロバクテリウムを使った植物の形質転換技術には特許の問 題がややこしくからんでくる。そのため（そして科学的 関心というもつと根本的な理由からも)、他の細菌種がア グロバクテリウムと同じように「植物遺伝子のエンジニア」 となれるかどうかを見極めたいとなって然るべきだろう。 他の細菌種を遺伝子操作して Ti プラスミドを運ぶように すると植物に癌腫を起こせることは、すでにいくつかの 論文で示されている ${ }^{7-9}$ 。しかし、これらの細菌から植物 へ本当にDNA が導入されたことを分子レベルで実証し た証拠はこれまでなかった。Broothaerts たちは今回、 この証拠を示したわけである

この研究では、細菌の 2 つの科の代表種である Rhizobium 種の NGR234、Sinorhizobium meliloti、Mesorhizobium lotiが使われた。Broothaerts たちはまず、 これらの細菌に T-DNA 領域を欠く無毒化した Ti プラス ミドを導入した。この Ti プラスミドには毒性遺伝子が含 まれている。そのタンパク質産物は T-DNA に㗢きかけ、 T-DNA を植物に導入するのに必要となる（図 2)。次に 


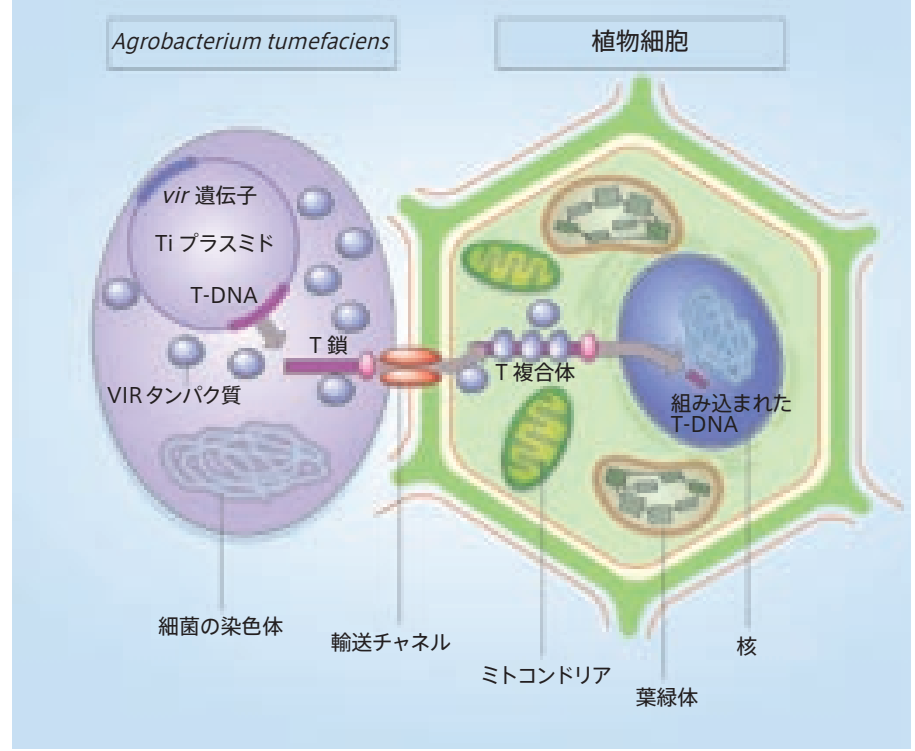

図 2 アグロバクテリウムが植物を遺伝的に形質転換させる仕組み。アグロ バクテリウムには腫瘍を引き起こすプラスミド (Ti プラスミド) があり、そ こには毒性 (vir) 遺伝子と導入された DNA (T-DNA) 領域が含まれる。こ の T-DNA に望む遺伝子を挿入できる。傷ついた植物細胞はフェノール類の 防御物質を産生し、この物質がアグロバクテリウムの vir 遺伝子を発現させ る。この遺伝子から作られた毒性（Vir）タンパク質がTi プラスミドから T-DNA 領域を切り出し、「丁鎖」を生じさせる。細菌が植物細胞に接着した あと、この T 鎖と数種類の Vir タンパク質が、輸送チャネルを通じて植物内 に運び込まれる。植物細胞内に入ると Vir タンパク質がT鎖と相互作用して $\mathrm{T}$ 複合体を形成する。この T複合体は核を目指し、T-DNA が植物ゲノムに入 り込んで自分にコードされている遺伝子を発現させる。

彼らは、T-DNA 領域を含む第 2 のプラスミドを、アグロ バクテリウム属でないこれらの細菌種と、無毒化したアグ ロバクテリウム菌株に導入した。この T-DNA には、抗生 物質ハイグロマイシンに対する耐性遺伝子と、マーカー酵 素である $\beta$-グルクロニダーゼを発現させる遺伝子を入れ てある。菌株の混合によってデー夕解釈を誤ることを防 ぐため、アグロバクテリウムとそうでない細菌種には違う

「分子夕グ」をT-DNA につけておいた。

Broothaerts たちはこれらの細菌を、高等植物の主要 2 群の代表種にあたる何種類かの植物種に感染させた。使っ た植物種は、双子葉植物（アグロバクテリウムによる形質 転換を非常に受けやすい) の夕バコとシロイヌナズナ、およ び単子葉植物 (アグロバクテリウムによる形質転換をあま り受けない) のコメである。 $\beta$-グルクロニダーゼを発現し ハイグロマイシンに耐性をもつ植物ができたことから、実 験したすべての細菌種で形質転換に成功したことが示さ れた。形質転換の成功は、DNA ブロット解析と、アグロバ クテリウム属以外の細菌種によって形質転換された植物か ら回収した T-DNA と植物 DNA の連結部分の塩基配列解 析によって確認された。さらに、これらの植物の T-DNA と植物 DNA の連結部分は、アグロバクテリウムによる形 質転換でできる連結部分と特徵が似通っていた。つまり、 異なる細菌種に由来する T-DNA のプロセシング、導入、 組み込みがおそらく同一の機構で起こったのだろう。

Broothaerts たちの研究結果からすると、アグロバクテ リウム属以外の細菌種でも、アグロバクテリウムに見られ
る遺伝的形質転換の機構をまったく同様に果たせると みられる。シロイヌナズナの形質転換には、雌性生殖細 胞 (生殖系列細胞) を標的とするフラワー・ディップ法を 要した ${ }^{10}$ 。しかしタバコとコメは体組織（それぞれ、葉と カルス細胞）を介して形質転換させており、これにはお そらく違う機構がからんでいる11。

今回さらにわかったのは、アグロバクテリウム属以外の 細菌種を遺伝子操作すれば、数種の植物を遺伝的に形質 転換させるようにできるものの、これらの形質転換効率 はアグロバクテリウム法の $1 \%$ 未満から約 $40 \%$ とかなり低 く、その值は使用した種と形質転換評価法に左右される いうことだ。ただし Broothaerts たちによれば、形質転 換条件（たとえば植え付けられた植物組織の年齢や型） を変えれば形質転換効率が高まる可能性はあるという。 多くの植物種は元々アグロバクテリウム法に「不応性」で 形質転換効率が低かったが、こうした操作によって効率 は過去 20 年でかなり向上した。

Broothaerts たちの発見 ${ }^{1}$ は間違いなく、植物の基礎科 学とバイオ技術に重大な意味をもつてくる。いくつかの 細菌種に植物への遺伝子導入能があるとわかったことで、 こうした遺伝子の水平移動が植物の進化に関与した可能 性が一段と濃厚になってきた。すでに知られているよう に、一部の植物種のゲノムには、A. rhizogenes が大昔に 引き起こした形質転換の名残が含まれている 12,13 。なか には、アグロバクテリウム由来の導入遺伝子が現在、寄主

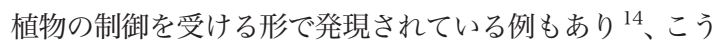
した遺伝子が植物の遺伝的構成の重要部分となっていっ たことがうかがわれる。同じょうにして他の細菌に由来 する導入遺伝子が植物に組み込まれた例も見つかるかも しれない。こうした遺伝子の受け渡しの仕組みや、こう した出来事が起こりうる生物の範囲が解明されていけば、 遺伝子の水平移動が高等生物の進化に大事だということ が理解されていくに違いない。

パーデュー大学 (米)、Stanton B. Gelvin

1. Broothaerts,W. et al. Nature 433, 629-633 (2005).

2. DeCleene, M. \& DeLey, J. Bot. Rev. 42, 389-466 (1976).

3. Gelvin, S. B. Microbiol. Mol. Biol. Rev. 67, 16-37 (2003).

4. Bundock, P., den Dulk-Ras, A., Beijersbergen, A. \& Hooykaas, P. J. J. EMBO J. 14, 3206-3214 (1995)

5. de Groot, M. J. A., Bundock, P., Hooykaas, P. J. J. \& Beijersbergen, A. G. M. Nature Biotechnol. 16, 839-842 (1998)

6. Kunik, T. et al. Proc. Natl Acad. Sci. USA 98, 1871-1876 (2001).

7. Klein, D. T. \& Klein, R. M. J. Bacteriol. 66, 220-228 (1953).

8. Hooykaas, P. J. J., Klapwijk, P. M., Nuti, M. P., Schilperoort, R. A. \& Rorsch, A. J. Gen.Microbiol. 98, 477-484 (1977).

9. van Veen, R. J. M. et al. Mol. Plant-Microbe Interact. 1, 231-234 (1988).

10. Desfeux, C., Clough, S. J. \& Bent, A. F. Plant Physiol. Biochem. 123, 895-904 (2000).

11. Mysore, K. S., Kumar, C. T. R. \& Gelvin, S. B. Plant J. 21, 9-16 (2000).

12. Furner, I. J. et al. Nature 319, 422-427 (1986).

13. Suzuki, K., Yamashita, I. \& Tannaka, N. Plant J. 32, 775-787 (2002)

14. Meyer, A. D., Ichikawa, T. \& Meins, F. Mol. Gen. Genet. 249, 265-273 (1995). 